\title{
Detection of Multidrug Resistant Strains in Some Pathogenic Bacteria and Fungi Caused Otitis in Pet Animals
}

\author{
Hanan A Fahmy ${ }^{1}$, Eman Mahrous ${ }^{2}$ and Rasha MH Sayed-Elahl ${ }^{3}$ \\ ${ }^{1}$ Department of Biotechnology; ${ }^{2}$ Department of Bacteriology; ${ }^{3}$ Department of Mycology; Animal Health Research \\ Institute (AHRI), Agriculture Research Center (ARC), Egypt \\ *Corresponding author: Eman_mahrous12@yahoo.com
}

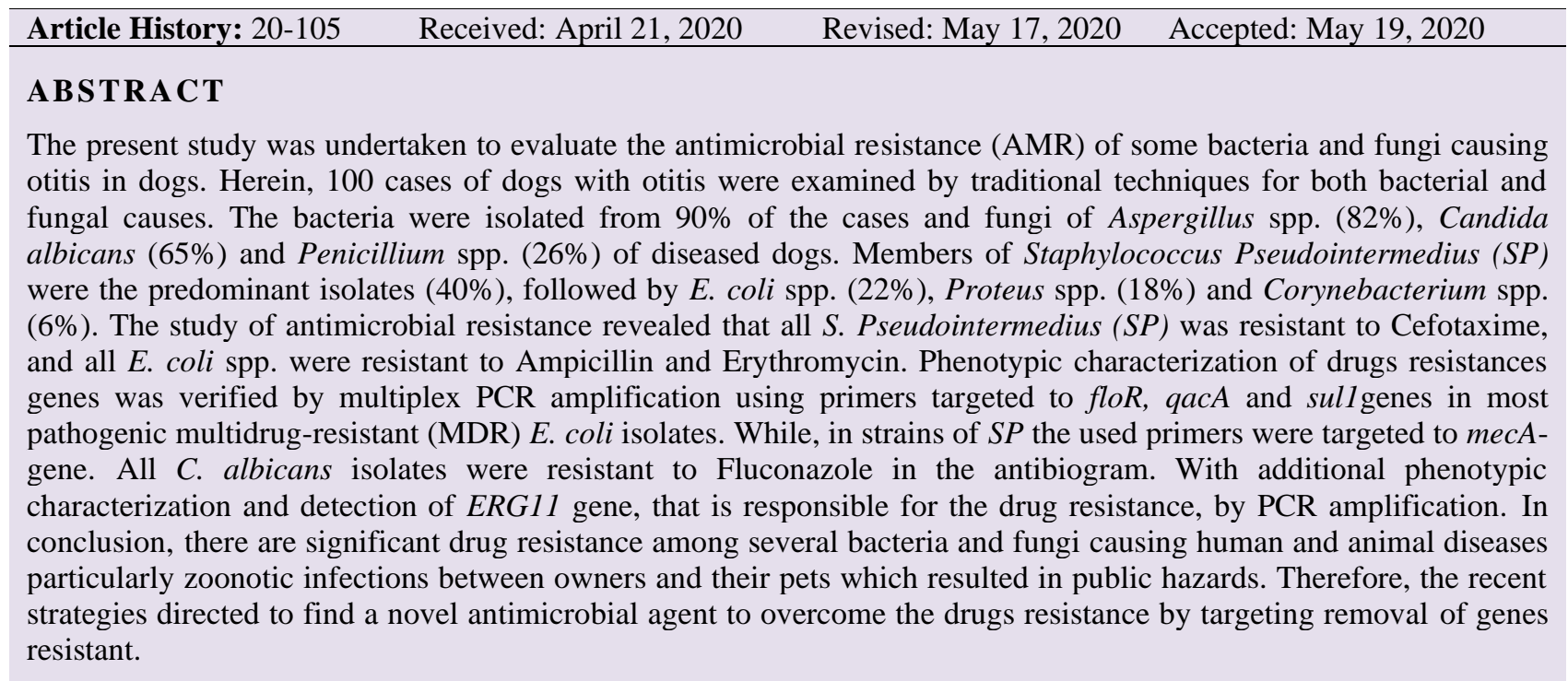

Key words: Otitis, Dogs, Antibiogram, $S P$, AMR.

\section{INTRODUCTION}

Pet animals can enrich our lives not only by offering comfort and companionship, but also by promoting an active, healthy life style and better mental well-being. On the other hand, they may act as reservoir of zoonotic diseases for human by direct contact with dogs' secretions and excretions (Mani and Maguire, 2009). The canine otitis is one of the most common diseases occurring as a secondary complication of primary factors that initiate inflammation within long pendulous ears with morbidity rates reach $20 \%$ of dogs (Cole, 2004). Furthermore, dog's ear infections had the potential to act as reservoirs of antimicrobial resistance (AMR) zoonotic pathogens, representing a huge problem in the control and therapy of human and animal diseases with potential threats to public health and to design efficient control strategies (Song and Lim, 2015). An emerging syndrome in veterinary and human medicine is methicillin-resistant $S$. Pseudointermedius (MRSP) or (SP) infections shared between pets and human handlers; it is one of the youngest members of the Staphylococcus genus, firstly described and recognized only in pets in 2005, in humans in 2006 and the first molecular identification protocol in 2009 (Gabriele et al., 2019).

The mechanism of resistance is dependent upon the production of an altered penicillin binding protein (PBP2a) which is encoded by mecA gene and Oxacillinmethicillin resistance is related to the mecA and its regulatory genes mecRl and mecI (Calazans-Silva et al., 2014). The bacteria of $E$. coli often carry multiple drug resistance plasmids and mixing of species in the intestines allows $E$. coli to accept or transfer plasmids from one to another under stress as horizontal gene transfer (Salyers et al., 2004). Fluconazole resistance of candidiasis by mutations in the ERG11 gene has been studied by Rosana et al. (2015). Therefore, this study was undertaken to investigate the prevalence of bacteria and fungi in otic dogs, evaluate the antibiogram of the isolated pathogens and AMR genes by traditional PCR.

Cite This Article as: Eman Mahrous, HA Fahmy and RMH Sayed-Elahl, 2020. Detection of multidrug resistant strains in some pathogenic bacteria and fungi caused otitis in pet animals. Int J Vet Sci, 9(3): 453-457. www.ijvets.com (C2020 IJVS. All rights reserved) 


\section{MATERIALS AND METHODS}

Ethical approval: This study was approved by the Institutional Animal Health Research Ethics Committee and in accordance with local laws and regulations.

Samples: A total of 100 clinical samples were collected from pet dogs, using a regular tipped culture from each ear separately. The samples were transferred to the laboratory as soon as possible within $2 \mathrm{hrs}$. and stored at $4^{\circ} \mathrm{C}$ for no longer than seven days before being kept frozen at $-80^{\circ} \mathrm{C}$ until analysis.

Each sample was divided into two parts, one for bacteriological and other for mycological examinations.

Isolation and Identification of Bacteria from were done as the standard methods recommended by Quinn et al. (2002). Isolation and Identification of $S P$ was done acc.to AnandaChitra et al. (2015).

Isolation and Identification of fungi from samples: were done according to the technique recommended by ISO (2008) and Pitt and Hocking (2009).

Antibiogram activity of antibacterial and antifungal was measured by disc diffusion test (Gupta and kohli, 2003; CLSI, 2018). The most predominant isolates from cases of otitis in dogs were used for further study. Spores suspensions from each strain were prepared from 1 week old and adjusted to $10^{5} / \mathrm{ml}$. In sterile plates, $1 \mathrm{ml}$ of the spores were added and covered with agar medium (MHA or SDA) then the mixed by rotation agitation over table. After solidification of medium, the discs of antibacterial /antifungal agents were spread over agar plates in rotatory manner. The used antimicrobial agents were amikacin (30 $\mu \mathrm{g})$, Ampicillin $(10 \mu \mathrm{g})$, Aztreonam $(30 \mu \mathrm{g})$, Cefotaxime $(30 \mu \mathrm{g})$, Clindamycin $(2 \mu \mathrm{g})$, Erythromycin $(15 \mu \mathrm{g})$, Emoxclav $(30 \mu \mathrm{g})$, Epicoflosin $(5 \mu \mathrm{g})$, Ofloxacin $(5 \mu \mathrm{g})$, Oxacillin $(1 \mu \mathrm{g})$, Rifampicin $(5 \mu \mathrm{g})$ and Tetracycline (30 $\mu \mathrm{g})$ Oxoid. While, the used Antifungals were as Fluconazole $(10 \mu \mathrm{g})$, Voriconazole $(1 \mu \mathrm{g})$, Itraconazole $(10 \mu \mathrm{g})$, Nystatin $(100 \mu \mathrm{g})$ and AmphotericinB $(100 \mu \mathrm{g})$ Oxoid. All plates were incubated for $2-5$ days at $28-37^{\circ} \mathrm{C}$ (for fungi) and for $24-48 \mathrm{hr}$. at $37^{\circ} \mathrm{C}$ (for bacteria). The experiment was repeated three times to pooled data.

Genotyping of drug resistance in E. coli, $S P$ and $C$. albicans that recovered from otitis in dogs

Genomic DNA of the strains was obtained using the RAPD (boiling) method; finally, the template for amplification was obtained and stored at $-20^{\circ} \mathrm{C}$ until used.

The PCR amplification of E. Coli was used primers selection for genes associated with florfenicol (floR), Quaternary ammonium compound (qacA) and sulfonamide (sul1), they were detected by Multiplex PCR amplification. Their primer sequences and predicted sizes for PCR amplification are listed in Table (1). Primers were prepared in Sigma Company also for mecA gene of $S$. pseudointermedius and for ERG11 gene for detection of C. albicans in Table (2).

While, PCR amplification of ERG11 gene for detection of $C$. albicans as follows $25 \mu$ of 2 x PCR Master mix Solution, $1.8 \mu 110 \mathrm{mM}$ each primer $15.4 \mu \mathrm{l}$ water (PCR grade); $6 \mu$ l DNA diluted. Cycling conditions as follow, $95^{\circ} \mathrm{C}$ for $2 \mathrm{~min}, 38$ cycles of $95^{\circ} \mathrm{C}$ for $30 \mathrm{~s}, 56^{\circ} \mathrm{C}$ for $30 \mathrm{~s}$ and
$72{ }^{\circ} \mathrm{C}$ for $2 \mathrm{~min}$; and final extension at $72{ }^{\circ} \mathrm{C}$ for $10 \mathrm{~min}$. in Bio-Rad thermocycler.

Reference positive and negative control was included in program performed in Bio-Rad (USA).

Table 1: The oligonucleotide primers used in Multiplex PCR reactions for the detection of antimicrobial resistance genes.

\begin{tabular}{llcc}
\hline Gene & Primer sequence (5' to 3') & $\begin{array}{c}\text { Expected } \\
\text { size bp }\end{array}$ & Reference \\
\hline $\begin{array}{l}\text { qacA-F } \\
\text { qacA-R }\end{array}$ & GCAGAAAGCAGGCAGAGTTCG & 361 & $\begin{array}{c}\text { Chuanchuen } \\
\text { et al., 2007 }\end{array}$ \\
floR-F & AACCCGCCCTCTGGATCAAGT & 548 & $\begin{array}{c}\text { Ghoddusi } \text { et } \\
\text { al., 2015 }\end{array}$ \\
floR-R & CAA & & \\
& CAAATCACGGGCCACGCTGTAT & & \\
Sul1-F & GTGACGGTGTTCGGCATTCT & 779 & Lanz et al., \\
Sull-R & TCCGAGAAGGTGATTGCGCT & & 2003 \\
\hline
\end{tabular}

Table 2: Primer sequence for $m e c A$ gene for MRSP. and for $E R G 11$ gene for detection of $C$. albicans.

\begin{tabular}{|c|c|c|c|c|}
\hline Gene & Primer sequence (5'-3') & $\begin{array}{c}\text { Size } \\
\text { bp }\end{array}$ & $\begin{array}{c}\text { Gene } \\
\text { Bank } \\
\text { No. }\end{array}$ & Reference \\
\hline $\begin{array}{l}\text { mecA-F } \\
\text { mecA-I }\end{array}$ & $\begin{array}{l}\text { AAAATCGATGGTAAAGGT TGGC } \\
\text { AGTTCTGCAGTACCGGATTTGC }\end{array}$ & 533 & Y00688 & $\begin{array}{l}\text { Kang et al., } \\
2014\end{array}$ \\
\hline $\begin{array}{l}C A-\mathrm{F} \\
C A-\mathrm{R}\end{array}$ & $\begin{array}{l}\text { ATGGCTATTGTTGAAACTG } \\
\text { TTAAAACATACAAGTTTCTCTT }\end{array}$ & 1587 & & $\begin{array}{l}\text { Rosana et } \\
\text { al., } 2015\end{array}$ \\
\hline
\end{tabular}

\section{RESULTS AND DISCUSSION}

The problem of AMR is ongoing worldwide in human and animals' health especially the zoonotic infections in pet animals. Veterinary clinicians, in contact with pet animals, must understand this problem to properly deal with and treat zoonotic diseases in pets.

The current results in (Table,3) revealed that the most predominant isolates were S. pseudointermedius (36\%), Proteus spp. (16\%), E. coli $(20 \%)$ and Corynebacterium $(6 \%)$. Higher isolation rate of SP has been reported by Lyskova et al., (2007) (58\%) and AnandaChitra et al., (2015) (59\%). Lower findings were detected by Oliveira et al., (2008) (18\%). An almost similar isolation rate was noticed by Petrov et al., (2018) (43.6\%). Herein, the prevalence of Gram-negative bacteria is nearly similar to that obtained by Lyskova et al. (2007) and Oliveira et al. (2008).

In the present work, the examined dogs' ear swabs were found to incriminate several fungal species as Aspergillus spp. were detected in 22 cases as single infection and 60 cases as mixed infection with a total incidence of (82\%) (Table 4). While, C. albicans were recovered 20 cases as single infection and 45 cases as mixed infection with other fungi with total incidence of $(65 \%)$. Other fungi were also recovered as Penicillium spp. and Rhizopus spp. Several studies detected Candida in dogs which suffered from disseminated candidiasis (Refai et al., 2016)

Currently, the recovered bacterial isolates from the present samples were subjected to evaluation of the antibiotic resistance where the antibiogram of all $E$. coli strains were resistant to AM and ERY (Table 5). While, all Klebsiella isolates were resistant to ERY and all Proteus isolates were resistant to AM and these findings were similar to those of Malayeri et al. (2010) and Petrov 
et al. (2018). In the present study (Table, 6) the isolated gram-positive bacteria, Coryneb. spp. showed higher resistance to ERY (83\%), as regards to resistance dominating $S P$. isolated from otitis in dogs to penicillin which came in accord with data obtained by Oliveira et al. (2008). While, the high resistance to tetA in our results was similar to findings of Malayeri et al. (2010), but lower resistance was detected by Boerlin et al. (2005) with respect to AM and gentamicin. Herein, the majority of the isolated $S$. pseudointermedius showing MDR profile with its antibiogram which is similar to Oliveira et al. (2008). Although it may be classified as a normal inhabitant of canine ear but it has a great zoonotic potential and high MDR profiles (Ventrella et al., 2017).

Regarding the AMR in isolated fungi from the present samples, the described results in (Table, 7), the fluconazole-resistant strains were Penicillium spp. (100\%), C. albicans (100\%), A. niger (90\%), A. ochraceous (80\%), A. flavus (70\%), respectively. Moreover, these strains that were resistant to voriconazole were Penicillium spp. (100\%), A. flavus (80\%) and other strains were observed lower resistance (60\% of each). The growth of $C$. albicans isolated strains was sensitive and fully inhibited by treatments with itraconazole and Nystatin (100\%) and other fungi showed variable sensitivity (50-90\%). While, amphotericin $\mathrm{B}$ had a moderate inhibitory effect on all tested fungi $(50 \%$ in each). Most of fungal pathogens cause several local and systemic infections in human and animals especially in immunodeficient hosts (Esmailzadeh et al., 2018). Frequent and long-term treatments by azoles initiated drugs resistance among the treated fungal pathogens (Cowen, 2008).

Table 3: Isolated bacterial pathogens from ear swabs.

\begin{tabular}{lcc}
\hline Bacterial type & \multicolumn{2}{c}{ Total } \\
\cline { 2 - 3 } & Number & $\%$ \\
\hline S. pseudointermedius & 36 & 40 \\
Klebsiella spp. & 12 & 13 \\
E.coli spp. & 20 & 22 \\
Corynebacterium spp. & 6 & 7 \\
Proteus spp. & 16 & 18 \\
Total & 90 & 90 \\
\hline
\end{tabular}

$\%$ : was calculated according to the total number of bacterial isolates.

Table 4: Isolated fungal pathogens from ear swabs.

\begin{tabular}{lcccc}
\hline Fungal type & $\begin{array}{c}\text { Pure } \\
\text { growth }\end{array}$ & $\begin{array}{c}\text { Mixed with other } \\
\text { fungi }\end{array}$ & \multicolumn{2}{c}{ Total } \\
\cline { 4 - 5 } Aspergillus spp. & 22 & 60 & Number & $\%$ \\
A. flavus & 8 & 24 & 32 & 82 \\
A. niger & 2 & 12 & 14 & 14 \\
A. ochraceous & 8 & 18 & 26 & 26 \\
A. terrus & - & 4 & 4 & 4 \\
A. candidus & 4 & - & 4 & 4 \\
A. versicolor & - & 2 & 2 & 2 \\
C.albicans spp. & 20 & 45 & 65 & 65 \\
Penicillium spp. & 12 & 14 & 26 & 26 \\
Rhizopus spp. & 2 & - & 2 & 2
\end{tabular}

$\%$ : was calculated according to the total number of fungal isolates.

In the present study, the genotypic characterization of MDR genes by PCR amplification on the isolated E. coli, $S P$. and C. albicans was undertaken.
Regarding MDR E. coli, the used primers were targeted to the genes of floR, qacA and sull and a variable gene expression were detected (Fig. 1). The resistance genes of $E$. coli to tetracyclines, sulfonamides, and streptomycin or spectinomycin were present in most samples, similar to that detected by Feria et al. (2002). Another study, illustrated that the presence of more than one drug resistance gene was due to repeated exposure to therapeutic agents that rarely occurred by tetA (4\% of 318 isolates) but more frequently $15 \%$ for sulfonamides (Boerlin et al., 2005). It is detected that the drug resistance rate of $E$. coli for 12 antibiotics by disc diffusion test ranged from (42\%-83.3\%) (Amer et al., 2018).

Currently, as observed in (Fig. 2), all of our tested $S P$ strains showed significant $m e c A$-gene expression which correlated with the phenotypes by disc diffusion test (Table 6). These findings came in accordance with Kang et al. (2014), who detected a strong correlation between phenotypic and genotypic methods for detection of antibiotic susceptibility tests. Here, all tested strains of $S P$, which were MDR, were also observed by (Vanni et al., 2009). The majority of the resistant SP strains resulted positive for mecA gene for oxacillin resistance; these findings were coming in accord with that detected in previous study as $100 \%$ for mecA gene amplification in MRSP strains (Gabriele et al., 2019).

On the other hand, the molecular detection of MDR genes of C.albicans for commercial antifungals used primer targeted CA gene at 1587 bp. were evaluated (Fig. 3).

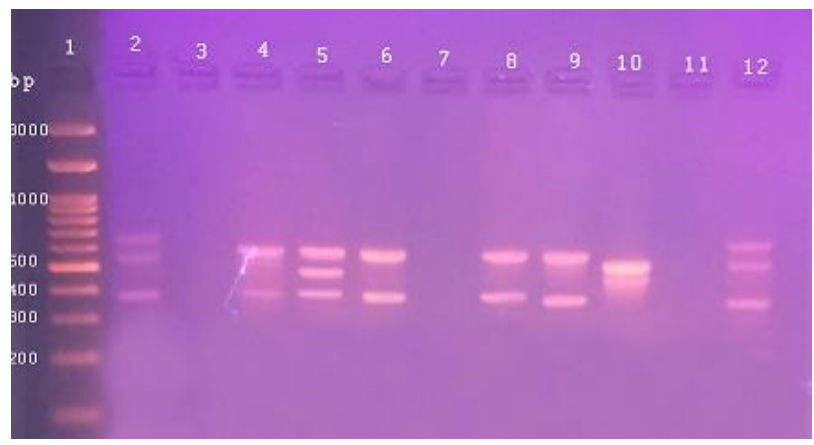

Fig. 1: Multiplex PCR for detection of AMR genes, sull, floR and qac $\mathrm{A}$ of $E$. coli. of approximately 779, 548 and $361 \mathrm{bp}$ respectively. Lane 1: 100bp ladder. L2: +ve control, L3: -ve control. Lane 4-12: isolates.

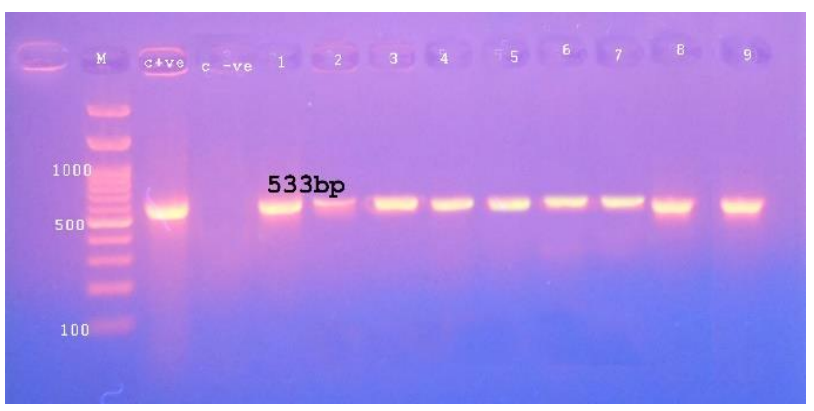

Fig. 2: PCR identification of the mecA gene at approximately 533bp. Lane M: Gene Ruler 100bp plus DNA ladder ready to use. +ve and -ve controls are included. Lane 1-9: Positive mecA gene of $S P$. isolates. 
Int J Vet Sci, 2020, 9(3): 453-457.

Table 5: Antibiogram of the isolated Gram-negative bacteria from samples of otitis in dogs.

\begin{tabular}{|c|c|c|c|c|c|c|c|c|}
\hline \multirow[t]{3}{*}{ Antimicrobial agent } & \multirow[t]{3}{*}{ Symbol } & \multirow{3}{*}{ Conc $\mu \mathrm{g} / \mathrm{disc}$} & \multicolumn{6}{|c|}{ Diameter zone of inhibition } \\
\hline & & & \multicolumn{2}{|c|}{ E. $\operatorname{coli}(20)$} & \multicolumn{2}{|c|}{ Klebsiella (12) } & \multicolumn{2}{|c|}{ Proteus (16) } \\
\hline & & & $\mathrm{S}$ & $\mathrm{R}$ & $\mathrm{S}$ & $\mathrm{R}$ & $\mathrm{S}$ & $\mathrm{R}$ \\
\hline Amikacin & AK & 30 & $18(90 \%)$ & $2(10 \%)$ & $3(25 \%)$ & $9(75 \%)$ & $16(100 \%)$ & 00 \\
\hline Ampicillin & AMP & 10 & 00 & $20(100 \%)$ & 00 & $12(100 \%)$ & 00 & $16(100 \%)$ \\
\hline Aztreonam & ATM & 30 & $13(65 \%)$ & $7(35 \%)$ & $7(58 \%)$ & $5(42 \%)$ & $4(25 \%)$ & $12(75 \%)$ \\
\hline Cefotaxime & CTX & 30 & $15(75 \%)$ & $5(25 \%)$ & $2(16 \%)$ & $10(83 \%)$ & $13(81 \%)$ & $3(19 \%)$ \\
\hline E-moxclav & AMC & 30 & $17(85 \%)$ & $3(15 \%)$ & $2(16 \%)$ & $10(83 \%)$ & $1(6 \%)$ & $15(94 \%)$ \\
\hline Epicoflosin & AFX & 5 & $20(100 \%)$ & 00 & $10(83 \%)$ & $2(16 \%)$ & $13(81 \%)$ & $3(19 \%)$ \\
\hline Erythromycin & ERY & 15 & 00 & $20(100 \%)$ & $1(8 \%)$ & $11(92 \%)$ & $15(94 \%)$ & $1(6 \%)$ \\
\hline Meropenem & MEM & 10 & $19(96 \%)$ & $1(4 \%)$ & $11(92 \%)$ & $1(8 \%)$ & $16(100 \%)$ & 00 \\
\hline Ofloxacin & OFX & 5 & $7(35 \%)$ & $13(65 \%)$ & $4(33 \%)$ & $8(67 \%)$ & $2(12.5 \%)$ & $1487.5 \%)$ \\
\hline
\end{tabular}

Table 6: Antibiogram of the isolated Gram-positive bacteria from samples of otitis in dogs.

\begin{tabular}{|c|c|c|c|c|c|c|}
\hline \multirow[t]{3}{*}{ Antimicrobial agent } & \multirow[t]{3}{*}{ Symbol } & \multirow{3}{*}{$\begin{array}{l}\text { Conc. } \\
\mu \mathrm{g} / \mathrm{disc}\end{array}$} & \multicolumn{4}{|c|}{ Diameter zone of inhibition } \\
\hline & & & \multicolumn{2}{|c|}{ S. pseudointermedius (36) } & \multicolumn{2}{|c|}{ Coryneb.spp. (6) } \\
\hline & & & $\mathrm{S}$ & $\mathrm{R}$ & $\mathrm{S}$ & $\mathrm{R}$ \\
\hline Amikacin & $\mathrm{AK}$ & 30 & $6(17 \%)$ & $30(83 \%)$ & - & - \\
\hline Ampicillin & $\mathrm{AM}$ & 10 & $10(28 \%)$ & $26(72 \%)$ & & \\
\hline Cefotaxime & Ctx & 30 & 00 & $36(100 \%)$ & & \\
\hline Clindamycin & DA & 2 & $36(100 \%)$ & 00 & - & - \\
\hline E-moxclav & AMC & 30 & $8(22 \%)$ & $28(78 \%)$ & - & - \\
\hline Erythromycin & ERY & 15 & $7(19 \%)$ & $29(81 \%)$ & $1(17 \%)$ & $5(83 \%)$ \\
\hline Oxacillin & OXA & 1 & $6(17 \%)$ & $30(83 \%)$ & - & - \\
\hline Rifampicin & $\mathrm{RD}$ & 5 & $17(47 \%)$ & $19(53 \%)$ & $3(50 \%)$ & $3(50 \%)$ \\
\hline Tetracycline & OT & 30 & $3(8 \%)$ & $33(92 \%)$ & - & - \\
\hline
\end{tabular}

Table 7: Antimicrobial sensitivity profile results of isolated Fungi from samples of otitis in dogs.

\begin{tabular}{|c|c|c|c|c|c|c|c|c|c|c|}
\hline \multirow{3}{*}{$\begin{array}{l}\text { Fungal } \\
\text { Isolates (Numbers) }\end{array}$} & \multicolumn{10}{|c|}{ Antifungal Agent } \\
\hline & \multicolumn{2}{|c|}{$\begin{array}{c}\text { Fluconazole } \\
(10 \mu \mathrm{g})\end{array}$} & \multicolumn{2}{|c|}{$\begin{array}{c}\text { Voriconazole } \\
(1 \mu \mathrm{g})\end{array}$} & \multicolumn{2}{|c|}{$\begin{array}{c}\text { Itraconazole } \\
(10 \mu \mathrm{g})\end{array}$} & \multicolumn{2}{|c|}{$\begin{array}{c}\text { Nystatin } \\
100 \mu \mathrm{g})\end{array}$} & \multicolumn{2}{|c|}{$\begin{array}{c}\text { AmphotericinB } \\
(100 \mu \mathrm{g})\end{array}$} \\
\hline & $\mathrm{R}$ & $\mathrm{S}$ & $\mathrm{R}$ & $\mathrm{S}$ & $\mathrm{R}$ & $\mathrm{S}$ & $\mathrm{R}$ & $\mathrm{S}$ & $\mathrm{R}$ & $\mathrm{S}$ \\
\hline A.flavus (10) & $7(70 \%)$ & $3(30 \%)$ & $8(80 \%)$ & $2(20 \%)$ & $1(10 \%)$ & $9(90 \%)$ & $2(20 \%)$ & $8(80 \%)$ & $5(50 \%)$ & $5(50 \%)$ \\
\hline A.niger (10) & $9(90 \%)$ & $1(10 \%)$ & $6(60 \%)$ & $4(40 \%)$ & $2(20 \%)$ & $8(80 \%)$ & $3(30 \%)$ & $7(70 \%)$ & $5(50 \%)$ & $5(50 \%)$ \\
\hline A.ochraceous (10) & $8(80 \%)$ & $2(20 \%)$ & $6(60 \%)$ & $4(40 \%)$ & $1(10 \%)$ & $9(90 \%)$ & $1(10 \%)$ & $9(90 \%)$ & $5(50 \%)$ & $5(50 \%)$ \\
\hline Penicillium spp. (10) & $10(100 \%)$ & 00 & $10(100 \%)$ & 00 & $4(40 \%)$ & $6(60 \%)$ & $5(50 \%)$ & $5(50 \%)$ & $5(50 \%)$ & $5(50 \%)$ \\
\hline C.albicans (10) & $10(100 \%)$ & 00 & $6(60 \%)$ & $4(40 \%)$ & 00 & $10(100 \%)$ & 00 & $10(100 \%)$ & $5(50 \%)$ & $5(50 \%)$ \\
\hline
\end{tabular}

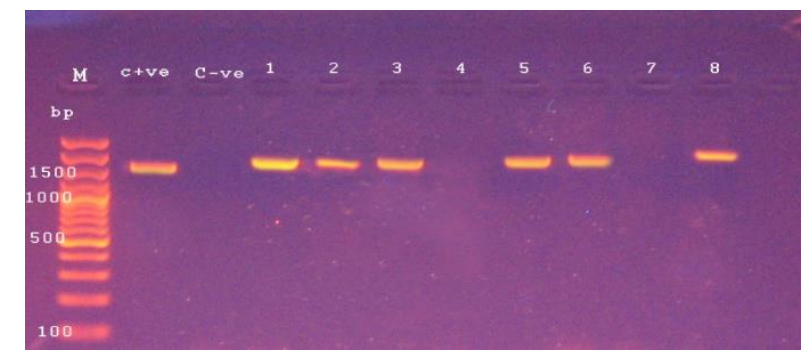

Fig. 3: Agarose gel electrophoresis of PCR amplicon for (1587bp) fragment obtained with DNA of C. albicans strains; M: 100-bp DNA ladder. +ve and -ve controls: Lane 1,2,3,5,6,8: positive PCR products: Lane 4and 7: negative results.

The results revealed that there was a direct correlation between conventional disc diffusion tests and genotypic characterization by PCR. These findings came in agreement with the findings reported by Rosana et al. (2015) who detected multi-azoleresistant (fluconazole, itraconazole and/or voriconazole). C. albicans isolates used primers targeted to (ERG11 gene). The failure to treat Candidemia by Fluconazole (FLC) is due to calciumactivated-calcineurin which reduced the in-vivo sensitivity of $C$. albicans to FLC by blocking the fungal plasma membrane to antifungals (Jia et al., 2012). This mechanism and the clinical impact of antifungal drug resistance were confirmed by Sanguinetti et al. (2015) which are essential for exploring the efficient antifungals against Candida infection and improving treatment outcomes.

\section{Conclusions}

The AMR is a critical health issue all over the world increasing global threat for treatment for pathogen and the correlation of phenotypic and genotypic evaluation must be undertaken. Hence, the strategies of exploring a novel antimicrobial agent to overcome the present MDR problem must be forwarded for prospective safety of human and animal health.

Recommendations for health care of pet animals: From the foregoing results, the source of zoonotic human infections from pet animals must be under guides of healthy precautions to avoid problems. The following health precautions should be undertaken:

A) Wash your hands: always wash your hands with soap and water for at least $20 \mathrm{sec}$. right after touching, feeding, caring for your pets or cleaning their habits and also supervise your baby hands' cleaning.

B) Play safely: don't kiss, snuggle or hold pet animals close to your face, avoid rough play with animals to prevent bites or scratches. Avoid eating, drinking around animals or touching your mouth after handling pets.

C) Keep it clean: clean up after animals properly. Keep their supplies out of kitchens or other areas where food is 
prepared, served, stored or consumed. Clean habitats, toys and other the house when it is possible.

D) Feed pets safely: avoid feeding raw diets, wash your hands properly after handling pet food or treats.

E) Veterinary supervision: with regular visits with vaccination program. Finally, Remember, healthy pets = healthy people.

\section{Acknowledgements}

The authors gratefully acknowledge Prof. Dr. El Sayed El Sawy, Chief Researcher of Microbiology, Animal Health Research Institute, Giza, Egypt for his help and support and advice.

\section{REFERENCES}

AnandaChitra M, Jayanthy C, Nagarajan B, 2015. Detection and sequence analysis of accessory gene regulator genes of Staphylococcus pseudintermedius isolates. Vet World, 8(7): 902-907.

Amer MM, Mekky HM, Amer AM, et al., 2018. Antimicrobial resistance genes in pathogenic $E$. coli isolated from diseased broiler chickens in Egypt and their relationship with the phenotypic resistance characteristics. Vet World, 11: 1082-88.

Boerlin P, Travis R, Gyles CL, et al., 2005. Antimicrobial Resistance and Virulence Genes of E. coli Isolates from Swine in Ontario. Applied Envirom Microb, 71: 6753-61.

Calazans-Silva AC, Medeiros PTC, Araujo DM, et al., 2014. Genetic analysis of mecA gene and detection of homologue pbpD in S. sciuri group. Braz J Microbiol, 45.

Chuanchuen R, Khemtongm S, Padungtod P, 2007. Occurrence of qacE/qacEDelta1 genes and their correlation with class 1 integrons in salmonella enterica isolates from poultry and swine. Southeast Asian J Trop Med Public Health, 38(5):855-62.

CLSI, 2018. Performance Standards for Antimicrobial Susceptibility Testing. CLSI Approved Standard. Clinical and Laboratory Standard Institute, Wayne, PA.

Cole LK 2004. Otoscopic evaluation of the ear canal. The Veterinary clinics of North America. Small animal practice, 34: 397-410.

Cowen LE 2008. The evolution of fungal drug resistance: Modulating the trajectory from genotype to phenotype. Nat Rev Microbial, 6: 187-98.

Esmailzadeh A, Zarrinfar H, Fata A, et al., 2018. High prevalence of candiduria due to non-albicans Candida species among diabetic patients: A matter of concern? J Clin Lab Anal, 32: e22343.

Feria CE, Ferreira JD, Goncalves CJ, et al., 2002. Patterns and mechanisms of resistance to beta-lactams and betalactamase inhibitors in uropathogenic E. coli isolated from dogs in Portugal. J Antimicrob Chemother, 49:77-85.

Gabriele M, Joel F, Lorenzo D, et al., 2019. Investigation of antibiotic resistance, biofilm formation and virulence factors in multidrug resistant and non-multidrug resistant Staphylococcus Pseudointermedius. Microorganisms, 7: 702 doi: 10.3390 .

Ghoddusi A, Fasaei BN, Karimi V, et al.,2015. Molecular identification of Salmonella Infantis isolated from backyard chickens and detection of their resistance genes by PCR. Iranian j of vet Res, 16(3): 293-297.

Gupta Ak and Kohli Y, 2003. In-vitro susceptibility testing of ciclopirox, terbinafine, Ketoconazole and Itraconazole against dermatophytes and non-dermatophytes, and in vitro evaluation of combination antifungal activity. $\mathrm{Br} \mathrm{J}$ Dermatol, 149: 296-305.

ISO 21527-2, 2008. Microbiology of food and animal feedings stuffs - Horizontal method for the enumeration of yeasts and moulds - Part 2: colony count technique in products with water activity less than or equal to 0.95 .

Jia Y, Tang R, Wang L, et al., 2012. Calcium activated calcineurin reduces the in-vitro and in-vivo sensitivity of fluconazole to candida albicans via Rta2p. PLoS One, 7: e48369.

Kang MH, Chae MJ, Yoon JW, et al., 2014. Antibiotic resistance and molecular characterization of ophthalmic Staphylococcus pseudintermedius isolates from dogs. J Vet Sci, 15: 409-415.

Lanz R, Kuhnert P, Boerlin P, 2003. Antimicrobial resistance and resistance gene determinants in clinical E. coli from different animal species in Switzerland. Vet Microbiol, 91: 73-84.

Lyskova P, Vydrzalova M, Mazurova J, 2007. Identification and antimicrobial susceptibility of bacteria and yeasts isolated from healthy dogs and dogs with otitis externa. J Vet Med Physiol Pathol Clin Med, 54(10): 559-63.

Malayeri HZ, Jamshidi S and Salehi TZ, 2010. Identification and antimicrobial susceptibility patterns of bacteria causing otitis externa in dogs. Vet Res Comm, 34: 435-44.

Mani I and Maguire JH, 2009. Small animal zoonoses and immunocompromised pet owners. Top Companion Anim Med, 24: 164-74.

Oliveira LC, Leite CA, Brilhante RS, et al., 2008. Comparative study of the microbial profile from bilateral canine otitis externa. Canadian Vet J, 49(8): 785-8.

Penna B, Varges R, Medeiros L, et al., 2009. Species distribution and antimicrobial susceptibility of staphylococci isolated from canine otitis externa. Vet Dermatology, 21: 292-296.

Petrov V, Zhelev G, Marutsov P, et al., 2018. Microbiological and antibacterial resistance profile in canine otitis externaa comparative analysis. Bulg J Vet Med, 1311-1477.

Pitt JJ and Hocking AD, 2009. "Fungi and Food Spoilage." 3rd Ed. Published by Spriiger Dordrech Heidelberg, London, New York.

Quinn PJ, Markey BK, Carter ME, et al., 2002. Vet. Microb. and Microbial. Disease, Great Britian by MPG, BOOK, Ltd., UK, 461-4.

Refai MK, Abou El-Yazeed H, Abdel-Haleem M, et al., 2016. Monograph on fungal diseases of cats and dogs A guide for postgraduate students.

Rosana Y, Yasmon A, Lestari DC, 2015. Overexpression and mutation as a genetic mechanism of fluconazole resistance in $C$. albicans isolated from human immunodeficiency virus patients in Indonesia. Medical Microbiol, 64: 104652.

Salyers AA, Gupta A, Wang Y, 2004. Human intestinal bacteria as reservoirs for antibiotic resistance genes. Trends Microbiol, 12: 412-416.

Sanguinetti M, Posteraro B, Lass-Flör C, 2015. Antifungal drug resistance among Candida species: mechanisms and clinical impact, 58: 2-13.

Stefani S and Varaldo PE, 2003. Epidemiology of methicillin resistance staphylococci in Europe. Clin Microbiol Infect 9: 1179-1186.

Song H and Lim S, 2015. Assessing pet industry in Korea using service quality improvement gap model. Int J Tech, Policy and Management, 15: 2-20.

Vanni M, Tognetti R, Pretti C, et al., 2009. Antimicrobial susceptibility of $S$. intermedius and $S$. schleiferi isolated from dogs. Res Vet Sci, 87: 192-5. 